\title{
Cleaning ability of rotary NiTi systems with different kinematics
}

\author{
Amira Galal Ismail ${ }^{1 *}$ D, Mohamed Mokhtar Nagy ${ }^{2}$ and Manar Galal ${ }^{1}$
}

\begin{abstract}
Background: The aim of this study was to compare the cleaning ability of rotary NiTi systems with different kinematics: ProTaper Next (PTN) (continuous rotation motion), WaveOne Gold (WOG) (reciprocating motion), and Twisted File Adaptive (TFA) (adaptive motion).

Methodology: Sixty mesiobuccal roots from extracted mandibular molars were divided into three groups $(n=20)$ : PTN, prepared by ProTaper Next; WOG, prepared by WaveOne Gold system; and TFA, prepared by Twisted File Adaptive systems. Teeth were longitudinally split into two halves for evaluation by scanning electron microscope. Images were analysed for debris and smear layer scores using the scoring system described by Hülsmann et al. ( $J$ Endod 23:301-6, 1997).

Results: No significant difference was found between the three groups in the coronal one third $(P=0.071)$. However, the TFA group recorded a significantly higher percentage of debris in the middle and apical thirds $(P<$ 0.001 and $P<0.001$, respectively)

Conclusions: Under the conditions of this study, adaptive motion produced more debris than the reciprocating and the continuous rotating motions.
\end{abstract}

Keywords: Adaptive motion, Cleaning ability, Continuous rotation, Kinematics, Reciprocation

\section{Introduction}

Successful root canal treatment depends on a significant reduction of microorganisms through chemo-mechanical instrumentation of the root canal system (Averbach \& Kleier, 2006; Hülsmann et al., 2005). Canal preparation is considered one of the critical factors that are directly related to efficient disinfection and subsequently the treatment outcome. Root canal preparation using rotary nickel-titanium instruments has become popular over the past two decades. However, currently, no instrument is capable of complete cleaning of the entire root canal system (Hülsmann et al., 1997; Gambarini \& Laszkiewicz, 2002; Schafer \& Schlingemann, 2003; Usman et al., 2004; Haapasalo et al., 2005; Arvaniti \& Khabbaz, 2011). Initially, the progress of nickel-titanium (NiTi) systems has been focused on variations in file design together with the simplification of the instrumentation sequences (Peters \& Paque, 2010; Shen et al., 2013). More recently, novel heat

\footnotetext{
* Correspondence: amirgalal@gmail.com

${ }^{1}$ Restorative and Dental Material Department, National Research Centre,

Cairo, Egypt

Full list of author information is available at the end of the article
}

treatment approaches together with manufacturing procedures have been introduced to improve the cyclic fatigue resistance of the rotary files (Plotino et al., 2017; Gambarini et al., 2008; Rodrigues et al., 2011).

Another approach adopted by the manufacturers to improve the performance of the instruments is changing the rotation kinematics during root canal preparation (Çapar \& Arslan, 2016). Reciprocation motion was presented to reduce stress values achieved by the instrument during rotation through travelling to a shorter angular distance than rotation motion does (Silva et al., 2016; Plotino et al., 2015). Additionally, the adaptive motions are composed of both continuous and reciprocation motion (Marks Duarte et al., 2018). To our knowledge, the current literature is lacking the effect of different kinematics on the cleaning efficiency of the rotary systems.

The aim of the present study was to compare the effect of different kinematics on the cleaning efficiency of ProTaper Next (Dentsply Sirona, Ballaigues, Switzerland), WaveOne Gold (Dentsply Sirona, Ballaigues, Switzerland), 
and Twisted File Adaptive (SybronEndo, Orange, CA, USA)

\section{Materials and methods Sample preparation}

Based on the data from previous studies (Bürklein et al., 2011; Bürklein et al., 2012), a power calculation was performed using G*Power 3.1 software (Faul et al., 2007) (Heinrich Heine University, Dusseldorf, Germany). The calculation indicated that the sample size for each group should be a minimum of 20 files. A total of 60 mesiobuccal roots from the extracted mandibular molars with curvatures ranging from 25 to $35^{\circ}$ were selected for this study. Only roots with completely formed roots and closed apices were included. Canal patency was confirmed by size $10 \mathrm{~K}$ file. The working length (WL) of the canal was established $1 \mathrm{~mm}$ short of where the file tip exits onto the root canal surface.

\section{Root canal instrumentation}

The roots were randomly divided into three groups $(n=$ 20): PTN, prepared by ProTaper Next system; WOG, prepared by WaveOne Gold; and TFA, prepared by Twisted file Adaptive systems. Homogeneity of the groups with respect to the degree of the curvature and radii was ensured using ANOVA (Table 1). All samples were prepared by the same operator using a gentle pecking up and down motion with an electric and torquecontrolled endodontic motor (X-Smart plus; Dentsply Sirona, Ballaigues, Switzerland) following the manufacturers' recommendations for each system.

In the PTN group, ProTaper Next files were used in the sequence $\mathrm{X} 1, \mathrm{X} 2$, and $\mathrm{X} 3$ corresponding to sizes 17/ $04,25 / 06$, and $30 / 07$, respectively, in a rotation motion.

In the WOG group, a primary reciprocating WaveOne Gold file having a size of 25 and a taper of 0.07 was used in a reciprocating, slow in-and-out pecking motion according to the manufacturer's instructions in a reciprocating motion.

In the TFA group, the instruments were operated by the Elements Motor (SybronEndo, Orange, CA, USA); file \#25.08 was used to prepare the cervical third; file \#25.06 was used up to $2 \mathrm{~mm}$ short of the working length, and files \#20.04, \#25.06, and \#25.08 were used up to the working length.

Intracanal irrigant used after each file was $3 \mathrm{~mL}$ of $2.25 \%$ sodium hypochlorite $(\mathrm{NaOCl})$ delivered by means

Table 1 homogeneity of curved root canals $(n=20)$

\begin{tabular}{lllll}
\hline & PTN & WOG & TF & $P$ value \\
\hline Curvature & $30.4 \pm 3.67$ & $30.6 \pm 3.48$ & $31.2 \pm 3.53$ & 0.76 \\
Radius & $6.13 \pm 1.45$ & $6.21 \pm 1.43$ & $6.15 \pm 1.38$ & 0.98 \\
\hline
\end{tabular}

of a 27-gauge needle and dried with absorbent paper points.

All root canal preparations were completed by one operator whereas the evaluation was carried out by a second operator who was blinded with respect to the experimental groups. Roots were split longitudinally and prepared for scanning electron microscope (SEM) investigation. Samples were examined under the SEM (Quanta 250 FEG, FEI Corporate, Hillsboro, OR, USA) at $\times 500-1500$ magnification. Separate evaluations were recorded for debris and smear layer. The cleanliness of each root canal was evaluated in three areas (apical, middle, and coronal third of the root) by means of a numerical evaluation scale (Hülsmann et al. 1997). The following scoring system was followed:

1. Debris (dentine chips, pulp remnants, and particles loosely attached to the canal wall): scoring of debris was performed using a $\times 500$ magnification.

(a) Score 1: clean canal wall, only very few debris particles

(b) Score 2: few small conglomerations

(c) Score 3: many conglomerations, 50\% less debris than of the canal wall covered

(d) Score 4: more than $50 \%$ of the canal wall covered

(e) Score 5: complete or nearly complete covering of the canal wall by debris

2. Smear layer (dentine particles, remnants of vital or necrotic pulp tissue, bacterial components, and retained irrigant): scoring of smear layer was performed using a $\times 1500$ magnification.

(a) Score 1: no smear layer, orifice of the dentinal tubule patent

(b) Score 2: small amount of smear layer, some open dentinal tubules

(c) Score 3: homogenous smear layer along almost the entire canal wall, only very few open dentinal tubules

(d) Score 4: the entire root canal wall covered with a homogenous smear layer, no open dentinal tubules

(e) Score 5: a thick, homogenous smear layer covering the entire root canal wall

The data recorded were analysed by the nonparametric Kruskal-Wallis test followed by the Mann-Whitney post hoc test. Statistical analysis was performed using statistical analysis software SPSS (Statistical Packages for the Social Sciences 20.0; IBM, Armonk, NY). Significant value was set at $P=0.05$.

\section{Results}

Representative samples are shown in Fig. 1 


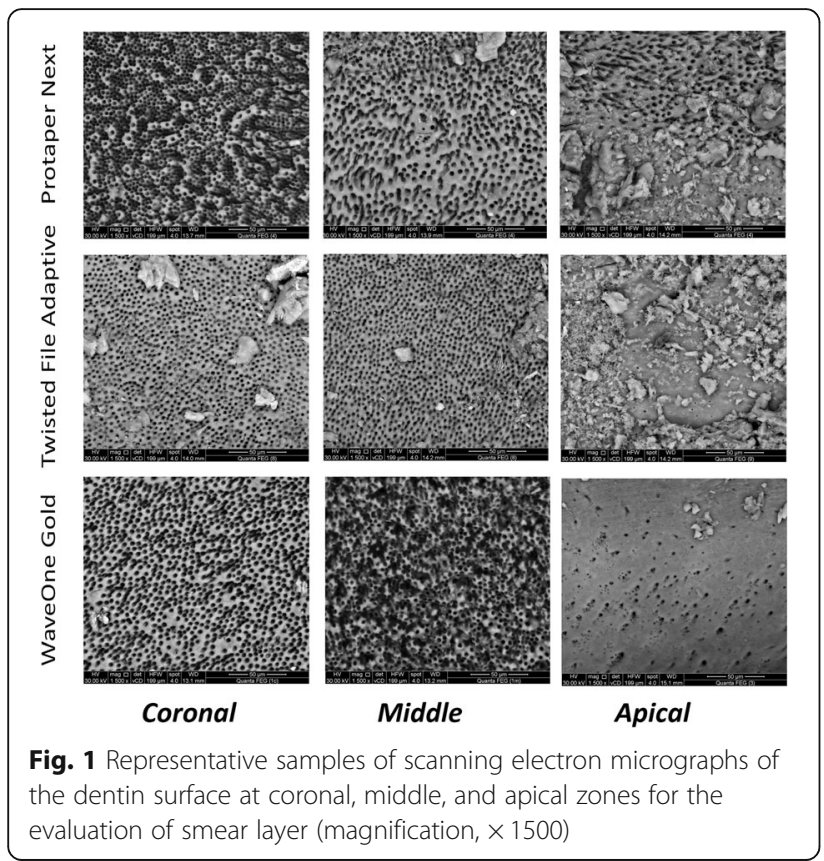

\section{Debris results (Table 2)}

\section{For the coronal groups}

There was no statistically significant difference between PTN, TFA, and WOG files where $P=0.071$.

The highest debris mean value was found in TFA $(2.20 \pm 0.77)$ followed by PTN $(1.66 \pm 0.72)$ while the least mean value of debris was found in WOG $(1.60 \pm 0.73)$. To PO: Please advise us on how to proceed regarding Author's response in Q7.

\section{For the middle groups}

There was a statistically significant difference between PTN, TFA, and WOG files where $P \leq 0.001$.

A statistically significant difference was found between PTN and TFA where $P \leq 0.001$. While no statistically significant difference was found between PTN and WOG files where $P=0.741$.

A statistically significant difference was found between TFA and WOG where $P=0.001$.

The highest debris mean value was found in TFA $(2.80 \pm 0.94)$ followed by WOG $(1.53 \pm 0.63)$ while

Table 2 Mean score for debris at the coronal, middle, apical thirds and overall of the canals

\begin{tabular}{lllll}
\hline System & Coronal & Middle & Apical & Overall \\
\hline PTN & $1.66 \pm 0.72^{\mathrm{a}}$ & $1.46 \pm 0.63^{\mathrm{a}}$ & $2.20 \pm 1.01^{\mathrm{a}}$ & $1.77 \pm 0.84^{\mathrm{a}}$ \\
WOG & $1.60 \pm 0.73^{\mathrm{a}}$ & $1.53 \pm 0.63^{\mathrm{a}}$ & $2.40 \pm 1.05^{\mathrm{a}}$ & $2.97 \pm 1.17^{\mathrm{b}}$ \\
TF & $2.20 \pm 0.77^{\mathrm{a}}$ & $2.80 \pm 0.94^{\mathrm{b}}$ & $3.93 \pm 1.09^{\mathrm{b}}$ & $1.84 \pm 0.90^{\mathrm{a}}$ \\
$P$ value & $0.071 \mathrm{~ns}$ & $\leq 0.001^{*}$ & $\leq 0.001^{*}$ & $\leq 0.001^{*}$ \\
\hline
\end{tabular}

Different superscript letters in the same column indicate statistically significant difference; "**" indicates significant $(P<0.05)$

ns non significant the least mean value of debris was found in PTN $(1.46 \pm 0.63)$.

\section{For the apical groups}

There was a statistically significant difference between PTN, WOG, and TFA files where $P \leq 0.001$

A statistically significant difference was found between PTN and TFA where $P=0.001$. While no statistically significant difference was found between PNT and WOG files where $P=0.602$.

A statistically significant difference was found between TFA and WOG where $P=0.001$.

The highest debris mean value was found in TFA $(3.93 \pm 1.09)$ followed by WOG $(2.40 \pm 1.05)$ while the least mean value of debris was found in PTN $(2.20 \pm 1.01)$.

\section{Smear layer results (Table 3) \\ For the coronal groups}

There was no statistically significant difference between PTN, TFA, and WOG files where $P=0.655$.

The highest smear layer mean value was found in PTN $(1.33 \pm 0.48)$ and TFA $(1.33 \pm 0.48)$ while the least mean value of smear layer was found in WOG $(1.20 \pm 0.41)$.

\section{For the middle groups}

There was no statistically significant difference between PTN, TFA, and WOG files where $P=0.314$.

The highest smear layer mean value was found in WOG $(1.53 \pm 0.51)$ and TFA $(1.46 \pm 0.51)$ while the least mean value of smear layer was found in PTN (1.26 \pm 0.45$)$.

\section{For the apical groups}

There was a statistically significant difference between PTN, TFA, and WOG files where $P=0.006$

A statistically significant difference was found between PTN and TFA where $P=0.011$. While no statistically significant difference was found between PTN and WOG files where $P=0.391$.

A statistically significant difference was found between TFA and WOG where $P=0.005$.

Table 3 Mean score for smear layer at the coronal, middle, and apical thirds and overall of the canals

\begin{tabular}{lllll}
\hline System & Coronal & Middle & Apical & Overall \\
\hline PTN & $1.33 \pm 0.48^{\mathrm{a}}$ & $1.26 \pm 0.45^{\mathrm{a}}$ & $2.20 \pm 0.77^{\mathrm{a}}$ & $1.60 \pm 0.71^{\mathrm{a}}$ \\
WOG & $1.33 \pm 0.48^{\mathrm{a}}$ & $1.46 \pm 0.51^{\mathrm{a}}$ & $3.06 \pm 1.03^{\mathrm{b}}$ & $1.95 \pm 1.06^{\mathrm{a}}$ \\
TF & $1.20 \pm 0.41^{\mathrm{a}}$ & $1.53 \pm 0.51^{\mathrm{a}}$ & $1.93 \pm 0.88^{\mathrm{a}}$ & $1.55 \pm 0.69^{\mathrm{a}}$ \\
$P$ value & $0.655 n \mathrm{~ns}$ & $0.314 n \mathrm{~ns}$ & $0.006^{*}$ & $0.206 \mathrm{~ns}$ \\
\hline
\end{tabular}

Different superscript letters in the same column indicate statistically significance difference; " ${ }^{* *}$ indicates significant $(P<0.05)$

ns non significant 
The highest smear layer mean value was found in TFA $(3.06 \pm 1.03)$ followed by PTN $(2.20 \pm 0.77)$ while the least mean value of smear layer was found in WOG $(1.93 \pm 0.88)$.

\section{Discussion}

The removal of the remaining pulp tissue, infected dentine, and most of the microorganisms from the root canal system is still one of the most important objectives during root canal instrumentation (Löst, 2006).

The aim of this study was to compare the cleaning efficiency of three rotary nickel-titanium systems using different kinematics in curved root canals of extracted human molar teeth.

Instrumentation of curved root canals always remains challenging not only for uniform canal shaping, but also for the proper cleaning of the root canal dentin. The teeth were balanced with respect to the angle and the radius of the canal curvature in which the homogeneity of the three groups was examined using analysis of variance (ANOVA) and post hoc Tukey test (Table 1).

The selected systems in this study represent three different kinematics: ProTaper Next, continuous rotation; WaveOne Gold, reciprocation; and Twisted File Adaptive, adaptive motion.

Debris and smear layer have been examined as the criteria to assess the cleaning efficiency because debris comprises dentine chips and residual vital or necrotic pulp tissue attached to the root canal wall that is considered to be infected in many cases (Hülsmann et al., 1997). Whereas the smear layer is the thin film consisting of predominantly inorganic material produced by canal instrumentation (Grandini et al., 2002). Therefore, the uninstrumented areas display no smear layer.

To avoid any impact of the irrigating solution, only $\mathrm{NaOCl}$ was used for its outstanding antibacterial effect and exclusive organic tissue-dissolving properties (TüRKüN \& CENGIZ, 2007). The cleaning efficiency was assessed using SEM evaluation on the basis of a numerical score for debris and smear layer of the coronal, the middle, and the apical parts of the canals (Hülsmann et al., 1997).

It has to be mentioned that area selection might be biassed, as cleaner sections might be preferred for scoring. This was overwhelmed by blinding the evaluator for the tested groups.

Adaptive motion recorded significantly higher scores than both rotation and reciprocating motions. This might be attributed to the continuously changing mode of operation which helps in packing of debris on the dentin walls rather than its clearance. This is very clear in the apical portion and not evident as we proceed coronally as the coronal areas are wide enough for debris removal via the mechanical action of irrigant. This is in agreement with many previous studies (Wu \&
Wesselink, 1995; Jiang et al., 2012; Siqueira et al., 2010). Other factors that might influence the amount of debris are the cutting efficiency of the instrument which depends on the file design, surface treatment, and heat treatment of the alloy (Baumann, 2004; Blum et al., 2003; Plotino et al., 2014). Further studies are necessary to investigate the influence of these factors on the remaining canal debris. On the other hand, both rotation and reciprocation motions showed comparable results of debris which was in agreement with other previous studies (Plotino et al., 2015; Bürklein et al., 2012; de Carvalho et al., 2016).

\section{Conclusion}

Under the conditions of this study, adaptive motion produced more debris than the reciprocating or the rotating motions.

\section{Abbreviations \\ ANOVA: Analysis of variance; NiTi: Nickel-titanium; PTN: ProTaper Next: SEM: Scanning electron microscope; SPSS: Statistical Packages for Social Sciences; TFA: Twisted File Adaptive; WL: Working length; WOG: WaveOne Gold}

\section{Acknowledgements}

Not applicable.

\section{Authors' contributions}

AGl prepared the specimens and analysed and interpreted the data. MMN wrote the manuscript. MG analysed the data and substantively revised the work. All authors read and approved the final manuscript.

\section{Authors' information}

Dr. Amira Galal is a graduate (2001) and postgraduate (Msc, 2009; PhD, 2015) of Cairo University, School of Oral and Dental Medicine. She is currently a researcher of endodontics at the National Research Centre and a part-time lecturer of endodontics at the Misr International University. Dr. Amira is also an FDI speaker and has lectured extensively nationally and internationally. Moreover, she has published articles in local and international journals. Dr. Amira operates at her own private practice "Dr. Amira Galal Dental Care" in New Cairo, Egypt.

Funding

None.

\section{Availability of data and materials}

The datasets used and/or analysed during the current study are available from the corresponding author on reasonable request. All data generated or analysed during this study are included in this published article

Ethics approval and consent to participate Not applicable.

\section{Consent for publication \\ Not applicable.}

\section{Competing interests}

The authors declare that they have no competing interests.

\section{Author details}

${ }^{1}$ Restorative and Dental Material Department, National Research Centre, Cairo, Egypt. ${ }^{2}$ Endodontic Department, Faculty of Dentistry, Ain Shams University, Cairo, Egypt. 
Received: 23 August 2019 Accepted: 10 September 2019

Published online: 23 December 2019

\section{References}

Arvaniti IS, Khabbaz MG (2011) Influence of root canal taper on its cleanliness: a scanning electron microscopic study. J Endod. 37(6):871-874

Averbach RE, Kleier DJ (2006) Clinical update on root canal disinfection. Compend Contin Educ Dent. 27(5):284 286-9

Baumann MA (2004) Nickel-titanium: options and challenges. Dent Clin N Am

Blum JY, Machtou P, Ruddle C, Micallef JP (2003) Analysis of mechanical preparations in extracted teeth using ProTaper rotary instruments: value of the safety quotient. J Endod.

Bürklein S, Hiller C, Huda M, Schäfer E (2011) Shaping ability and cleaning effectiveness of Mtwo versus coated and uncoated EasyShape instruments in severely curved root canals of extracted teeth. Int Endod J. 44(5):447-457

Bürklein S, Hinschitza K, Dammaschke T, Schäfer E (2012) Shaping ability and cleaning effectiveness of two single-file systems in severely curved root canals of extracted teeth: Reciproc and WaveOne versus Mtwo and ProTaper. Int Endod J. 45(5):449-461

Çapar ID, Arslan H (2016) A review of instrumentation kinematics of enginedriven nickel-titanium instruments. Int Endod J 49:119-135

de Carvalho FMA, Gonçalves LC de O, Marques AAF, Alves V, Bueno CE da S, De Martin AS (2016) Cleaning effectiveness of a reciprocating single-file and a conventional rotary instrumentation system. Open Dent J. 10(1):704-713

Faul F, Erdfelder E, Lang A-G, Buchner A (2007) G*Power 3: a flexible statistical power analysis program for the social, behavioral, and biomedical sciences. Behav Res Methods. 39(2):175-191

Gambarini G, Grande NM, Plotino G, Somma F, Garala M, De Luca M et al (2008) Fatigue resistance of engine-driven rotary nickel-titanium instruments produced by new manufacturing methods. J Endod. 34(8):1003-1005

Gambarini G, Laszkiewicz J (2002) A scanning electron microscopic study of debris and smear layer remaining following use of GT rotary instruments. Int Endod J. 35(5):422-427

Grandini S, Balleri P, Ferrari M (2002) Evaluation of Glyde File Prep in combination with sodium hypochlorite as a root canal irrigant. J Endod. 28(4):300-303

Haapasalo M, Endal U, Zandi H, Coil JM (2005) Eradication of endodontic infection by instrumentation and irrigation solutions. Endod Top. 10(1): 77-102

Hülsmann M, Peters OA, Dummer PMH (2005) Mechanical preparation of root canals: shaping goals, techniques and means. Endod Top. 10(1):30-76

Hülsmann M, Rümmelin C, Schäfers F (1997) Root canal cleanliness after preparation with different endodontic handpieces and hand instruments: a comparative SEM investigation. J Endod. 23(5):301-306

Jiang LM, Lak B, Eijsvogels LM, Wesselink P, Van Der Sluis LWM (2012) Comparison of the cleaning efficacy of different final irrigation techniques. J Endod.

Löst C (2006) Quality guidelines for endodontic treatment: consensus report of the European Society of Endodontology. Int Endod J. 39(12):921-930

Marks Duarte P, Barcellos da Silva P, Alcalde MP, Vivan RR, da Rosa RA, Duarte MAH et al (2018) Canal transportation, centering ability, and cyclic fatigue promoted by Twisted File Adaptive and Navigator EVO instruments at different motions. J Endod. 44(9):1425-1429

Peters OA, Paque F (2010) Current developments in rotary root canal instrument technology and clinical use: a review. Quintessence Int. 41(6):479-488

Plotino G, Ahmed HMA, Grande NM, Cohen S, Bukiet F (2015) Current assessment of reciprocation in endodontic preparation: a comprehensive review - part II: properties and effectiveness. J Endod 41:1939-1950

Plotino G, Giansiracusa Rubini A, Grande NM, Testarelli L, Gambarini G (2014) Cutting efficiency of Reciproc and WaveOne reciprocating instruments. J Endod. 40(8):1228-1230

Plotino G, Grande NM, Mercadé Bellido M, Testarelli L, Gambarini G (2017) Influence of temperature on cyclic fatigue resistance of ProTaper Gold and ProTaper Universal Rotary Files. J Endod. 43(2):200-202

Rodrigues RCV, Lopes HP, Elias CN, Amaral G, Vieira VTL, De Martin AS (2011) Influence of different manufacturing methods on the cyclic fatigue of rotary nickel-titanium endodontic instruments. J Endod. 37(11):1553-1557

Schafer E, Schlingemann R (2003) Efficiency of rotary nickel-titanium K3 instruments compared with stainless steel hand K-Flexofile. Part 2. Cleaning effectiveness and shaping ability in severely curved root canals of extracted teeth. Int Endod J 36:208-217
Shen Y, Zhou HM, Zheng YF, Peng B, Haapasalo M (2013) Current challenges and concepts of the thermomechanical treatment of nickel-titanium instruments. J Endod. 39(2):163-172

Silva EJNL, Villarino LS, Vieira VTL, Accorsi-Mendonça T, Antunes H dos S, De-Deus $\mathrm{G}$ et al (2016) Bending resistance and cyclic fatigue life of Reciproc, Unicone, and WaveOne reciprocating instruments. J Endod. 42(12):1789-1793

Siqueira JF, Alves FRF, Almeida BM, MacHado De Oliveira JC, Rôças IN (2010) Ability of chemomechanical preparation with either rotary instruments or self-adjusting file to disinfect oval-shaped root canals. J Endod. 36(11): 1860-1865

TüRKüN M, CENGIZ T (2007) The effects of sodium hypochlorite and calcium hydroxide on tissue dissolution and root canal cleanliness. Int Endod J.

Usman N, Baumgartner JC, Marshall JG (2004) Influence of instrument size on root canal debridement. J Endod. 30(2):110-112

Wu MK, Wesselink PR (1995) Efficacy of three techniques in cleaning the apical portion of curved root canals. Oral Surg Oral Med Oral Pathol Oral Radiol.

\section{Publisher's Note}

Springer Nature remains neutral with regard to jurisdictional claims in published maps and institutional affiliations.

\section{Submit your manuscript to a SpringerOpen ${ }^{\circ}$ journal and benefit from:}

- Convenient online submission

- Rigorous peer review

- Open access: articles freely available online

- High visibility within the field

- Retaining the copyright to your article

Submit your next manuscript at $\boldsymbol{\nabla}$ springeropen.com 